\title{
Using the instructional therapeutic play during admission of children to hospital: the perception of the family
}

\author{
Utilizando o brinquedo terapêutico instrucional durante a \\ admissão de crianças no hospital: percepção da família \\ Uso del juguete terapéutico instruccional durante la admisión \\ de los niños al hospital: la percepción de la familia
}

\section{Bruna Ferreira Aranha ${ }^{a}$ (D) Marcela Astolphi de Souza ${ }^{a}$ (B) Glicinia Elaine Rosilho Pedroso ${ }^{a}$ (1) Edmara Bazoni Soares Maiab Luciana de Lione Meloa ${ }^{a}$}

\section{How to cite this article:} Aranha BF, Souza MA, Pedroso GER, Maia EBS, Melo LL. Using the instructional therapeutic play during admission of children to hospital: the perception of the family. Rev Gaúcha Enferm. 2020;41:e20180413. doi: https://doi.org/10.1590/19831447.2020.20180413
Universidade Estadual de Campinas (UNICAMP) Faculdade de Enfermagem. Campinas, São Paulo, Brasil.

• Universidade Federal de São Paulo (UNIFESP), Escola Paulista de Enfermagem. São Paulo, São Paulo, Brasil.

\section{ABSTRACT}

Objective: To understand, from the family's perspective, the meaning of admitting the child in the hospital with the use of the instructional therapeutic play.

Method: A phenomenological research with 12 families of children aged four to nine years old, recently admitted to a public and teaching hospital, in the inland of the state of São Paulo, from October to December 2016. They participated in an instructional therapeutic play session focusing on the procedures performed at hospital admission: weight, height, and vital sign measurements and test collection. The families, in turn, were invited to participate in a phenomenological interview the day after the session.

Results: The instructional therapeutic play collaborated in the therapeutic procedures by understanding and modifying the child's behavior. Also stressed by the families was the need for the toy to be incorporated as nursing care.

Conclusion: Given the benefits to the child, the family believes that this strategy should be performed as a routine nursing care and, therefore, performed systematically during child hospitalization.

Keywords: Child, hospitalized. Play and playthings. Pediatric nursing. Nursing care.

\section{RESUMO}

Objetivo: Compreender, na perspectiva da família, o significado de admitir a criança no hospital com a utilização do brinquedo terapêutico instrucional.

Método: Pesquisa fenomenológica realizada com 12 famílias de crianças de quatro a nove anos, recém-admitidas em um hospital público e de ensino, no interior do Estado de São Paulo, no período de outubro a dezembro de 2016. Estas participaram de uma sessão de brinquedo terapêutico instrucional com foco nos procedimentos realizados na admissão hospitalar - aferição de peso, altura, sinais vitais e coleta de exames. As famílias, por sua vez, foram convidadas a participar de entrevista fenomenológica no dia seguinte à sessão. Resultados: 0 brinquedo terapêutico instrucional colaborou na compreensão dos procedimentos terapêuticos, modificando 0 comportamento da criança. Também foi ressaltada, pelas famílias, a necessidade de o brinquedo ser incorporado como cuidado de enfermagem.

Conclusão: Diante dos benefícios para a criança, a família acredita que esta estratégia deva ser executada como cuidado de enfermagem rotineiro e, portanto, realizada sistematicamente durante a hospitalização infantil.

Palavras-chave: Criança hospitalizada. Jogos e brinquedos. Enfermagem pediátrica. Cuidados de enfermagem.

\section{RESUMEN}

Objetivo: Comprender, en la perspectiva de la familia, el significado de hospitalizar al niño con el uso de un juguete terapéutico instructivo.

Método: Investigación fenomenológica realizada de octubre a diciembre de 2016 con 12 familias de niños de cuatro a nueve años, recién internados en un hospital público y de enseñanza, en el interior del estado de São Paulo. Participaron en una sesión de juguete terapéutico instructivo enfocada en los procedimientos realizados al momento de la internación: medición de peso, altura y signos vitales, y recolección de exámenes. Por su parte, se invitó a las familias a participar en una entrevista fenomenológica al día siguiente de la sesión. Resultados: El juguete terapéutico instructivo ayudó a comprender los procedimientos terapéuticos, modificando el comportamiento del niño. Las familias también resaltaron la necesidad de que el juguete se incorporara como cuidado de enfermería.

Conclusión: Dados los beneficios para el niño, la familia cree que esta estrategia debe implementarse como cuidado rutinario de enfermería y, por lo tanto, realizarse sistemáticamente al momento de la internación de los niños.

Palabras clave: Niño internado. Juego e implementos de juego. Enfermería pediátrica. Atención de enfermería. 


\section{口INTRODUCTION}

Humanized care implies understanding and valuing the human person as a subject inserted in a social context and with a previous history. For this, it is essential that the health team be sensitive and empathetic with each child-family binomial because, for them, humanized care encompasses the patient-professional approximation, effective and sincere communication, and emotional support, as well as the quality of child care ${ }^{(1)}$.

Thus, it can be said that humanized care aims at caring for the child in an integral way, that is, taking care of him considering the physical, emotional, social and spiritual needs, in addition to the family's inclusion. Accordingly, the Child and Adolescent Statute (Estatuto da Criança e do Adolescente, ECA) ensures that, when a child needs hospitalization, "health care facilities should provide conditions for the full-time stay of a caregiver", which is generally a family member ${ }^{(2: 12)}$.

This proposal is linked to the need for nursing to include the family in its work process and, thus, to take a broad look, based on the interpersonal relationships and the partnership among team, child and family, since one's well-being directly affects the other's condition ${ }^{(3)}$.

Aiming to provide assistance based on the National Humanization Policy (Política Nacional de Humanização, PNH), advocated by the Unified Health System (Sistema Único de Saúde, SUS) and, considering the child's needs and rights as determined by the ECA, the Federal Nursing Council (Conselho Federal de Enfermagem, COFEN), through Resolution No. 0546/2017, states that it is responsibility of the Nursing Team working in the pediatric area to use the Therapeutic Play (TP) technique to assist hospitalized children and their families. In addition, it states that the use of the TP can be performed by any nursing professional, as long it is supervised by a duly trained nurse ${ }^{(4)}$.

The inclusion of the TP in childcare reinforces playing as one of the intrinsic childhood needs, regardless of whether or not the child is ill, because childhood is a period marked by discoveries in which the child learns to deal with the world around him. Thus, playing acts as the child's work, enabling healthy development and favoring relationships with other people(5).

The TP consists of a non-directive technique, allowing the child through playing to express feelings, and to represent their internal and external world, not being a passive subject and becoming an active subject. In addition, the TP also helps to clarify misconceptions $s^{(3,6)}$.

In terms of its modalities, the TP can be instructional, dramatic or a trainer of the physiological functions. The Instructional Therapeutic Play (ITP) is used to prepare the child for hospitalization and therapeutic procedures; the Dramatic Therapeutic Play (DTP), on the other hand, allows children to express their feelings and relive unpleasant situations in an attempt to master them; finally, the Therapeutic Play for Training the Physiological Functions enables child to maintain or improve his physical condition ${ }^{(7)}$.

In view of this, the nurse, as one of the responsible for the child's care, must have, besides the scientific technical knowledge, affection, respect, empathy, creativity and playfulness attitudes, since it is necessary to establish a bond, as the hospital context has a great impact on children and families, causing fear, anxiety, anguish and behavioral changes ${ }^{(8)}$.

Thus, the toy/TP facilitates the professional-child interaction, favoring procedures performance in a less painful and invasive, and more humane way since, when a child needs to be hospitalized, he may be doubly ill, because he is deprived of the contact with his family and friends, with changes in her routine as well as frequent procedures ${ }^{(8)}$. The toy can also soften feelings of anger, depression and sadness arising from the child's association of hospitalization with a punishment ${ }^{(8-10)}$.

Therefore, the child's preparation for procedures in the hospital setting, such as weight, height, and vital sign measurements and the collection of tests, after hospital admission and especially using the therapeutic play, can provide positive results, since the TP is able to provide tranquility, courage and calm to children, facilitating communication, participation, acceptance of procedures and enabling the implementation of a non-traumatic care for children and their families ${ }^{(11)}$.

Given the above and understanding that the use of the instructional therapeutic play in the preparation for the hospital admission procedures seems ideal to minimize hospitalization adverse effects, favoring their understanding of the routine procedures and encouraging their participation in them, the following research question emerged: what is the family's perception about the use of the instructional therapeutic play when the child is admitted to the hospital?

Therefore, the purpose of this study is to understand, from the family's perspective, the meaning of admitting the child to the hospital using the instructional therapeutic play. 


\section{METHOD}

To unveil the phenomenon and seek to answer the research question "what is the family's perception of the use of the TP at the time of admission to the hospital?", and to guide him about the routine procedures such as weight, height, and sign vital measurements and the collection of tests, the chosen method was the qualitative research, especially with a phenomenological approach ${ }^{(12)}$.

Phenomenology seeks to understand the lived phenomena, which do not depend on causes, answers or explanations since, with each unveiling there is a contained veiling, causing more questions to emerge. It also seeks to understand the meaning that the subjects attribute when experiencing a given phenomenon, which is all that is shown, manifests itself and provokes questions ${ }^{(12-13)}$ in the conscience.

The research scenario was a Pediatric Inpatient Unit (PIU) of a public, tertiary teaching hospital located in the inland of the state of São Paulo. This study was approved in 2016 by a Research Ethics Committee, under Opinion No.1,682,576.

The inclusion criteria for this research were families of children from 3 to 10 years old, the recommended age group for the TP, recently admitted to the PIU, who had their children received through a ITP session focused on the hospital admission procedures: weight, height, and vital sign measurements, and collection of blood tests, lasting up to 30 minutes and performed on the child's bed. The exclusion criteria consisted of families of children who had some restriction on participating in the ITP session, such as children in precautionary care and/or with non-contacting neurological problems, in addition to those who did not belong to the recommended age group. The selection of the families was also intentional and assisted by the PIU health team, which indicated possible participants according to the aforementioned criteria.

As soon as the child and his family were received and sent to bed, the lead researcher invited the child to play. The game began with a story of a child who had to be in the hospital to receive care according to the needs of each child. All the admission procedures were performed on the doll presented to the child, always asking for his help, and subsequently inviting him to repeat the story, if he wanted to, in addition to solving possible doubts about the procedures.

The family stayed with the child, watching the game, without interrupting and/or participating. All the toys used in the ITP sessions followed the specific literature recommendation ${ }^{(6)}$.

Within 24 hours of the ITP session, the family member who accompanied the child during the session was invited to participate in an interview with the following guiding question: Tell me how it was for you to see your child (or other kinship) receiving information about hospitalization with the help of toys.

The interviews were conducted by the lead researcher from October to December 2016, with only her, the participant and sometimes the child present. The families were individually and personally invited, when the Free and and Informed Consent Form (FICF) was presented and their consent was requested. In addition, the Child Consent Form was presented to the children, described in graphic language from drawings showing a child playing in the hospital.

Thirteen families were invited, and 12 agreed to participate in the study. One mother refused to participate, but without justification, although the child did participate in the ITP session.

Confidentiality was granted to the family regarding the identity and the right to refuse or give up without any loss to the child on the care provided by the institution. The names of the family members were replaced by names of children's story characters. Thus, each participant was assigned the name of one of the seven Snow White's dwarves, of Princess Aurora's protective fairies from the Sleeping Beauty fable and of two friends of Dorothy's from The Wizard of $\mathrm{Oz}^{\circ}$ fable, so that the family members could be symbolized according to their behavior and relationship with the children.

Lasting up to 25 minutes, the interviews were recorded in digital audio and fully transcribed by the lead researcher, and were later analyzed according to Martins and Bicudo ${ }^{(12)}$ recommendations: global reading of the total speech content; attentive rereading, in order to identify units of meaning; with these units of meaning, convergences and divergences were sought; the thematic categories were elaborated and, later, the descriptive synthesis.

The interviews ended when the speeches were sufficient to help the researcher to unveil the phenomenon in question, that is, when theoretical saturation was reached ${ }^{(14)}$.

\section{- RESULTS AND DISCUSSION}

\section{Understanding the family's perspective on the child's hospital admission using the instructional therapeutic play}

From the discourse analysis, several phenomenon's facets were unveiled and understood through the following thematic categories: 
- Therapeutic Instructional Play: a strategy that drives changes in the child's behavior.

- Therapeutic Instructional Play: an effective collaboration in the child's understanding of the therapeutic procedures.

- Therapeutic Instructional Play: an essential nursing care for the child.

\section{Therapeutic Instructional Play: a strategy that drives changes in the child's behavior}

For the child and family, hospitalization is a period marked by changes in both physical and emotional character. The first is characterized by the change of setting, and by the imposition of routines and procedures, while the second is considered largely responsible for the possible psychological disorders and impairments in child development, characterized by behavior change, which can be perceived during hospitalization and/or later ${ }^{(15)}$.

The nursing professional using the ITP allows the child to be an active subject of their care ${ }^{(3,16)}$, which was evidenced in a comparative study that observed the differences in the behaviors between children who were and were not submitted to the ITP technique in relation to venipuncture ${ }^{(17)}$.

The children who received guidance on venipuncture through the ITP were more collaborative during the procedure, verbalizing their doubts and maintaining a relaxed posture ${ }^{(17)}$, which indicates a better management of children's pain and anxiety related to stressful and painful procedures ${ }^{(11)}$.

[...] she behaved well. I think in her head, she remembered what you did to her yesterday, teaching her, not moving her arm. I asked the girl if she bothered to get an injection, anything, she said it didn't do it at all. She's always remembering the little doll. (Bashful)

[...] Oh, I thought it was good because... when, after the doctors put in serum, you know? In her vein, she cried a little, but didn't scare that much. After you showed the toy she was calmer, as if it doesn't hurt. She didn't cry that much; she saw it was none of that. (Sneezy)

Therefore, some families reported that the ITP was important not to frighten the child and to promote tranquility at the time of the procedure. Despite this, a family member considered the difference in behavior as discrete, although significant. However, it is evident that the family member used the knowledge acquired at the time of preparation to explain and support the child.

[...] So she had a good improvement. I was different, for example when she collected blood yesterday, and take a medication I told her: "do you remember the little doll?" So you have to do like the little dol!!" So, she calmed down. So there was a difference, not much, but significant. Because she was very agitated, so I started talking to her, explaining, just as it was shown to her, and we had a good difference. (Sleepy)

Although the ITP technique had been performed with all the children, each individual is unique and reacts to the same situation in different ways ${ }^{(17)}$. The child's strangeness to the hospital setting can trigger a series of emotional manifestations, and the most common way for children to expose their discomfort, fear and pain is through crying ${ }^{(18)}$.

Thus, the families could see that, after the ITP sessions, some children kept crying during the procedures but, in contrast, changed aggressive behaviors towards the nursing staff. Supported in the rescuing of the family member from the experience of having been oriented with the ITP, the children referred to the situation shown with the doll and calmed down.

[...] Oh, she was calm; it was good that then you showed the doll. It was good for her to calm down a little. (Sneezy)

[...] is of the little doll you are talking about? Yeah, she allowed, she's allowing, only she's crying. She's crying. There are times when she doesn't want to take her medicine. She's slapping her [refers that the child tries to slap the hands of the professional performing the procedures], throws herself. But she's fine; she's allowing a lot. When I say her name and the doll's, she stays quiet, doesn't pull her arms, but cries, she still cries. (Grumpy)

In this study, one of the families emphasized the importance of using the ITP in preparing the child for the surgical procedure because, in previous hospitalizations, the issue of fasting was a stressful and difficult factor for the child to understand. After the use of the ITP, however, the preparation for the procedure was better accepted by the child, also favoring interaction with the team.

The literature reinforces this importance when it states that, after being prepared for a procedure using toys, children can better control their emotions and collaborate with the procedure to which they will be submitted ${ }^{(5,11)}$.

l expected another reaction from him. But he interacted very well. Then at night, when he went fasting, he didn't complain, it helped his treatment. Because at other times he complained, because he wanted to eat, but not this time. (Doc)

The more oriented the child is about what will happen to him, the less afraid he will feel. As the use of the therapeutic 
play helps to understand this reality, it enables him to experience the procedure to which he will be subjected in a concrete way. In addition, the literature states that children who do not receive an adequate prior preparation before an unknown and/or painful procedure have more difficulty coping with the reality and resort to fantasies ${ }^{(11)}$.

Thus, for the family, the ITP not only changed the child's behavior, but was also decisive for the child to understand the procedures to which he would be submitted.

\section{Therapeutic Instructional Play: an effective collaboration in the child's understanding of the therapeutic procedures}

The ITP is considered a communication tool by means of which children receive guidance from the professionals and clarify doubts, and may be able to minimize the negative effects of hospitalization ${ }^{(3)}$. When the child has the opportunity to manipulate hospital supplies during the ITP session, he is faced with the possibility to understand the procedures to be performed ${ }^{(19)}$.

In this study, from the family's perspective, the ITP collaborated with the child regarding the understanding of the therapeutic procedures, since both family and child remembered the doll used.

[...] she had an experience playing with the doll at night, for her it was a learning. (Bashful)

I was very calm when I realized that she understood that she knew what was going to happen to her. (Lion)

Playing during the ITP session enables the child to learn because it is an opportunity to deal with the invasive and potentially painful experience before actually experiencing it, relieving him from fear and anxiety, and sometimes from magical thoughts and/or misconceptions proper of this age ${ }^{(11)}$. The families in this study demonstrated such an understanding that the ITP allows the child to know in advance what will happen to him.

[...] it seems that he was understanding more. After playing, he understood the procedure more [...] It was better for me than taking him by surprise. (Happy)

During play, the child is free to create, and this experience becomes real for him, allowing him to understand the world around him $^{(11,19)}$. The child's previous preparation with the ITP contributes significantly to the predominance of indicative behaviors of the child's acceptance and adaptation to the situation, which corroborates Happy's speech quoted above ${ }^{(20)}$.
A study carried out in a children's outpatient clinic in the city of São Paulo, which aimed to identify the behaviors that children presented during vaccine application, with and without preparation through the ITP, concluded that the ITP facilitates the understanding and the acceptance of the nursing procedures ${ }^{(11)}$, which also corroborates the results of the present study.

The children who were prepared for surgery with the ITP expressed interest in hearing the story told about the procedure and were able to reproduce the information assimilated during the preparation ${ }^{(20)}$. Dopey ratifies this statement by verbalizing that telling a story during the ITP session enables the child to understand a particular circumstance.

[...] it was like a little story to him. To him, I mean, in fact he understood like this. (Dopey)

Considering that, during hospitalization, the child has already lived or will experience numerous experiences involving pain and suffering, it is relevant to emphasize that the child's preparation with the TP provides a better understanding of the moment and greater tranquility ${ }^{(16)}$. Even more so in cases of children from 2 to 7 , who are most vulnerable to the negative effects of hospitalization because they have their cognitive and emotional structures in progress $(7,17,20)$.

The TP is also inserted in the non-traumatic child care model, assuming the use of appropriate interventions to minimize or eliminate the children's and their families' physical and emotional suffering in the health care environment ${ }^{(16)}$, like the hospital, for example.

Therefore, the results indicate that it is imperative to use strategies such as the ITP, which will be better explained in the next thematic category, that enable children to cope with hostile situations inherent to their daily lives.

\section{Therapeutic Instructional Play: an essential nursing care for the child}

The use of the ITP technique is regulated by the COFEN since $2004^{(4)}$. However, nowadays we realize that, due to the lack of adequate nursing staff sizing for pediatric care ${ }^{(21)}$, we have a big gap in looking at the child and his family emotional situation.

In addition to the lack of this appropriate dimensioning, there is a need for contemplation of this theme in the training, so that nurses do not see it only as a task to be performed, but as a nursing care that will bring benefits to the child and, consequently, to his family ${ }^{(21)}$.

During the ITP sessions, some families mentioned that this type of care had never been performed in that unit, 
emphasizing that the child is often hospitalized in this setting, but that it is the first time with the ITP

[...] Because it never happened to us, we have been patients here for 10 years and it never happened. (Doc)

[...] / am very surprised by this care for my son because I have never seen this before. (Scarecrow)

Although the benefits arising from the TP are known, its use is still incipient by the nursing team professionals. Family members of hospitalized children in the inland of the state of Minas Gerais, for example, were surprised to have contact with the TP, which meets the literature when it states that the professionals know its importance in child care, but prioritize physical care ${ }^{(16)}$.

Another aspect pointed out was the difference among hospitals already attended.

\section{[...] It's a method that they don't have in the hospital. (Dopey)}

Playing, as mentioned earlier, is important for children in different contexts and for different purposes. The family, in turn, perceived the use of the ITP as an essential game during the hospitalization period, but it is up to the nursing staff to recognize the need and benefits of the TP, providing means for its realization and incorporating it systematically in the daily care of hospitalized children ${ }^{(17)}$.

[...] / found it essential; it is interesting that children get distracted. It's like a joke. (Fauna Fairy)

[...] I never saw it, nobody ever explained anything to her with a toy. (Lion)

The families of children undergoing the ITP sessions came to rely more on the health team, feeling reassured to see that the child received individualized care, considering such a favorable strategy as well as believing that it reduces fear and calms the child ${ }^{(11)}$.

In some speeches, the family members value the use of the ITP, understanding it as part of the care proved by the nursing professionals and recommending that it should be performed frequently in the hospital setting.

[...] It was great, you can continue doing it. (Fauna Fairy)

[...] / found it very interesting, essential, I found it very good.

[...] You should use it more here at the hospital. (Doc)

[...] Here the service was good for her. I thought it was good, I have nothing to say, I found it very good. (Spring Fairy)
The findings of this study reveal the importance of using the ITP for both children and their families, which corroborates the results of other research studies. These reinforce that the use of the ITP technique should consider the child in different contexts, in addition to hospitalization, considering play as essential for the child's development and favoring the bond with the professionals ${ }^{(16-18)}$.

However, even facing the existing limitations, the data from this study reinforced that the ITP is a relevant intervention for pediatric nursing, so as to enable less traumatic care based on the psychological, physical and emotional needs of children ${ }^{(17)}$.

Thus, this last category reveals the way the family members perceived the nursing role, which transcends caring for the physical body, as they emphasized in their speeches that the ITP should be performed frequently and in all hospitals, since it helped the child to accept the care, to cope with the hospitalization and also to distract him.

\section{- CONCLUSION}

The aim of this study was to understand, from a family perspective, the meaning of admitting the child to the hospital using the ITP. Through this care strategy, the families were unanimous in stating that admission has become more understandable for the child.

The family realized that the ITP helps the child to feel safer in coping with the hospitalization procedures and fears, as well as in the interaction and in establishing a bond of trust with the team.

In addition to the goal being achieved, the study advanced to show how much companions, present at the time of guidance, were able to support and give confidence to the child in moments when they showed fear or cried, rescuing the guidance received during the ITP session.

Even after 14 years of the enactment of COFEN's Resolution 295/2004, the TP is not yet present in the curriculum of all Brazilian undergraduate nursing courses, i.e., nurses finish the course without having any theoretical and/or practical approach to the subject in question, even if it is their responsibility. This situation makes it difficult for the TP to be used in any scenario where the child is assisted or valued by the health team. In addition, it is important to remember that the ITP is a fast, simple and inexpensive action, considered an advanced nursing care used whenever necessary, and especially in the hospital admission of all children, in order to minimize the impact of hospitalization.

Given the benefits pointed out by the families in this study, the TP should be incorporated into nursing interventions, including being described in the nursing process 
as well as in any other nursing care. It is intended that this research awakens the health professionals to envision new forms of care for hospitalized children.

This study was limited to understanding the family's perception of the use of the TP during the child's admission. However, other studies may understand the nurses' perspective, as they are responsible for the use of this strategy.

\section{口EFERENCES}

1. Andrade RC, Marques $A R$, Leite $A C A B$, Martimiano RR, Santos BD, Pan R, et al. Necessidades dos pais de crianças hospitalizadas: evidências para o cuidado. Rev Eletr Enf. 2015;17(2):379-94. doi: https://doi.org/10.5216/ree.v17i2.30041

2. Câmara dos Deputados (BR). Estatuto da Criança e do Adolescente: Lei no 8.069, de 13 de julho de 1990, e legislação correlata. 16a ed. Brasilia (DF): Edições Câmara; 2017 [cited 2018 Sep 10]. Available from: https://central3.to.gov.br/ arquivo/407632/

3. Caleffi CCF, Rocha PK, Anders JC, Souza AlJ, BurciagaVB, Serapião LS. Contribution of structured therapeutic play in a nursing care model for hospitalised children. Rev Gaúcha Enferm. 2016;37(2):e58131. doi: https://doi.org/10.1590/19831447.2016.02.58131

4. Conselho Federal de Enfermagem (BR). Resolução no 0546/2017, de 09 de maio de 2017. Atualização da norma para utilização da técnica do Brinquedo/ Brinquedo Terapêutico pela Equipe de Enfermagem na assistência à criança hospitalizada. Brasilia (DF): Cofen; 2017 [cited 2018 Sep 10]. Available from: http://www.cofen.gov.br/wp-content/uploads/2017/05/RES.-546-17.pdf

5. Ribeiro RLR, Fonseca ES, Borba RIH, Ribeiro CA. Education, health and citizenship: strategies to the warranty of the rights of hospitalized children and adolescents. R Educ Públ. 2013 [cited 2018 Apr 29];22(49/2):503-23. Avallable from: http://periodicoscientificos.ufmt.br/ojs/index.php/educacaopublica/article/ viewFile/930/731

6. Green $C S$. Understand children's need through therapeutic play. Nursing. 1974;4(10):31-2.

7. Vessey JA, Mahon MM. Therapeutic play and the hospitalized children. J Pediatr Nurs. 1990;5(5):328-33.

8. Facio BC, Matsuda LM Higarashi IH. Pediatric rooming-in: understanding the negotiation between nurses and caregivers. Rev Eletr Enf. 2013;15(2):447-53. doi: https://doi.org/10.5216/ree.v15i2.17419

9. Rockembach JA, Espinosa T, Cecagno D, Thumé E, Soares DC. Insertion of play as facilitator of hospitalization in childhood: parental perception. J Nurs Health. 2017 [cited 2019 Jul 29];7(2):117-26. Available from: https://periodicos.ufpel. edu.br/ojs2/index.php/enfermagem/article/view/7646/7882
10. Sabino AS, Esteves AVF, Oliveira APP, Silva MVG. The parents' knowledge on the care process through play. Cogitare Enferm. 2018 [cited 2019 Jul 29];23(2):e52849. Available from: https://revistas.ufpr.br/cogitare/article/ view/52849/pdf

11. Pontes JED , Tabet E, Folkmann MAS, Cunha MLR, Almeida FA. Therapeutic play: preparing the child for the vaccine. Einstein. 2015 [cited 2018 May 02];13(2):238-42. Available from: http://apps.einstein.br/revista/arquivos/ PDF/2967-238-242_port.pdf

12. Martins J, Bicudo MAV. Pesquisa qualitativa em psicologia: fundamentos e recursos -básicos. 5a ed. São Paulo: Centauro; 2005.

13. Santos RP, Neves ET, Carnevale F. Qualitative methodologies in health research: interpretive referential of Patricia Benner. Rev Bras Enferm. 2016 ;69(1):192-6. doi: https://doi.org/10.1590/0034-7167.2016690125i

14. Frank, JR. (I can't get no) Saturation: a simulation and guidelines for sample sizes in qualitative research. PLoS One. 2017;12(7):e0181689. doi: https://doi. org/10.1371/journal.pone.0181689

15. Coyne I, Holmström I. Centeredness in healthcare: a concept synthesis of familycentered care, person-centered care and child-centered care. J Pediatr Nurs. 2018:42:45-56. doi: https://doi.org/10.1016/j.pedn.2018.07.001

16. Figueiredo CR, Lima CA, Prado PF, Leite MT. Brinquedo terapêutico no cuidado integral à criança hospitalizada: significados para o familiar acompanhante. Rev Unimontes Cient. 2015 [cited 2017 0ct 18];17(2). Available from: http://www. ruc.unimontes.br/index.php/unicientifica/article/view/401/337

17. Lemos ICS, Oliveira JD, Gomes EB, Silva KVL, Silva PKS, Fernandes GP. Brinquedo terapêutico no procedimento de punção venosa: estratégia para reduzir alteraç̧ões comportamentais. Rev Cuidarte. 2016;7(1):1163-70. doi: https:// doi.org/10.15649/cuidarte.v7i1.303

18. Gomes GC, Nicola GDO, Souza NZ, Chagas MCS, Farias DFR, Xavier DM. Percepções da família acerca das dificuldades de adaptaçãão da criança à hospitalização: subsídios para a enfermagem. Cogitare Enferm. 2013;18(4):767-74. doi: https://doi.org/10.5380/ce.v18i4.34935

19. Pennafort VPS, Queiroz MVO, Gomes ILV, Rocha MFF. Brinquedo terapêutico instrucional no cuidado cultural da criança com diabetes tipo 1. Rev Bras Enferm. 2018;71(suppl 3):1415-23. doi: https://doi.org/10.1590/0034-7167-2017-0260

20. Paladino CM, Carvalho R, Almeida FA. Therapeutic play in preparing for surgery: behavior of preschool children during the perioperative period. Rev Esc Enferm USP. 2014;48(3):423-9. doi: https://doi.org/10.1590/50080623420140000300006

21. Oliveira CS, Maia EBS, Borba RIH, Ribeiro CA. Brinquedo Terapêutico na assistência à criança: percepção de enfermeiros das unidades pediátricas de um hospital universitário. Rev Soc Bras Enferm Ped. 2015[cited 2018 Nov 28];15(1):21-30. Available from: https://sobep.org.br/revista/images/stories/ pdf-revista/vol15-n1/vol_15_n_2-artigo-de-pesquisa-3.pdf

\section{- Corresponding author:}

Marcela Astolphi de Souza

E-mail: marcela.astolphi@gmail.com

\section{Associate editor:}

Jéssica Machado Teles

\section{Editor-in-chief:}

Maria da Graça Oliveira Crossetti 